\title{
Financial Performance of Socially Responsible Firms: The Short- and Long-Term Impact
}

\author{
Maria J. Charlo ${ }^{1, *}$ (i) , Ismael Moya ${ }^{2}$ and Ana M. Muñoz ${ }^{1}$ \\ 1 Department of Accounting and Finance, University of Seville, 41018 Seville, Spain; amrubio@us.es \\ 2 Department of Economics and Social Sciences, Universitat Politècnica de València, 46022 Valencia, Spain; \\ imoya@esp.upv.es \\ * Correspondence: mjcharlo@us.es; Tel.: +34-954-556-043
}

Received: 7 September 2017; Accepted: 9 September 2017; Published: 13 September 2017

\begin{abstract}
The pressure of society for firms to adopt socially responsible behavior is evident. Yet, Corporate Social Responsibility (CSR) needs an economic justification. In response to this, there exists a comprehensive literature that analyzes the possible relation between social and business financial performance. During the last decade, the literature has been heading toward the carrying out of dynamic studies as researches find that the relationship between social and financial performance is not static. The purpose of this work is to analyze the relevance for the financial performance of Spanish listed firms of maintaining their responsible behavior. To do so, we carry out a comparison between two analyses-one cross-sectional, and the other longitudinal-to be able to conclude whether or not adopting responsible criteria makes a difference in business financial performance in the short and long-term. Some of the results obtained in the cross-sectional study are consolidated in the long-term study. In this sense, responsible firms exhibit a higher systematic risk and have greater size. As a conclusion, be responsible does not mean less stock profitability or a lower business result. It certainly contributes to firms continuing to voluntarily incorporate good corporate social responsibility practices into their business models. What is more, these results support the governmental policies and initiatives that bolster corporate social responsibility.
\end{abstract}

Keywords: corporate social responsibility; social performance; financial performance; sustainable companies; sustainable index

\section{Introduction}

The possible nexus between corporate social responsibility (CSR) and financial performance continues being the cause of a continuous debate [1]. The broad literature on the topic in the last decade indicates that: (i) most of the studies on the topic focus on British or American enterprises [2]; (ii) the results obtained are contradictory and heterogeneous fundamentally due to the use of unique and are not very homogeneous measures of social responsibility [3]; and, (iii) there are differences in the relation between CSR and financial performance in the short and long-term [4].

Responding to the need for more research in the Spanish area and avoiding the use of single and hardly homogenous measures, we study the firms that belong to the sole Spanish responsible index: the FTSE4Good IBEX. It is a multidimensional indicator of responsible behavior whose criteria are made public at an international level. This is why, for the purposes of this work, firms that belong to the Spanish responsible index are considered socially responsible. It is understood that the firms that are listed in these indexes must have a greater social performance than those that are not in them. Due to this, firms that belong to this responsible index on an ongoing basis are credited with a better CSR management than those that have never been in the index.

A sustainable index for Spanish listed firms having existed since 2008 enables us to know those firms that stand out for their responsible behavior in the Spanish values market. The FTSE4Good IBEX 
is a part of the FTSE group of indexes, and is drawn up by the British ethical qualification agency EIRIS in collaboration with its Spanish partner ECODES. EIRIS is an organization funded by religious and charitable bodies to investigate firms' social, ethical and environmental policies and the advances that they make. The FTSE group announced in September 2013 that the group itself will administer the new rating methodology, which will deal with 14 sustainability topics and more than 300 specific indicators; ECODES is a foundation dedicated to the research and analysis of Spanish firms which are in the main stock market indexes.

Therefore, the composition of the indexes reflects the qualification these agencies award and which they are responsible for. Moreover, every year this composition is subject to a review process in March and September to check the firms' fulfillment of the social and environmental requirements.

The purpose of this work is to analyze the relevance for financial performance of firms maintaining their responsible behavior. To do so, we carry out a comparison between two analyses-one cross-sectional, and the other longitudinal— to be able to conclude whether or not adopting responsible criteria makes a difference in the business financial performance in the short and long-term.

The first analysis is a cross-sectional study carried out at the time of the publication of the Spanish responsible index. Here, we analyze the possible existence of differences in the financial behavior of the firms belonging to the FTSE4Good IBEX in 2008, when the index was published. We compare these firms to others that were not included in the index because of not meeting the requirements. To do so, we have carried out a discriminant analysis, a multivariate dependence technique that can detect a series of distinguishing characteristics that differentiate between two previously defined groups.

The second is a longitudinal study from 2008 to 2013. Its objective is to analyze if the firms which made up the FTSE4Good IBEX in 2008 and which were still in it in 2013, differ in their financial performance from those firms that have never been part of the sustainable index during this period. The methodology used is the Mixed analysis of variance (Mixed ANOVA), as it allows for the introduction of the time factor when comparing the mean value of the variables between the companies listed in the FTSE4Good IBEX social responsibility index and those firms that are not listed in that index.

Both studies mean to identify the possible differences in the financial behavior of the socially responsible firms with two distinct time horizons. Consequently, their results enable conclusions to be reached. These are about the relevance or non-relevance of maintaining responsible behavior and the appearance of differentiating aspects in the financial performance of the responsible index firms. In this sense, the most recent literature points out that it is in the long-term that the adopting of responsible criteria could be related with an improved financial performance.

To achieve our objective, the work has been divided into the following sections. After this introduction, we include a review of the extant literature concerning the different CSR approaches and its link with achieving financial results across different time horizons. Then, we present the empirical study that we carried out. Finally, there is a discussion of the results and our conclusions.

\section{Literature Review}

The main CSR theories can be grouped based on their predominant approach, according to how the relation between society and firms is envisaged [5].

The literature identifies three major CSR approaches [6] connected with different arguments: the regulation approach, linked to a moral obligation; the descriptive approach, related with aims of legitimacy and approval; and, the instrumental approach, based on corporate reputation. The strategic approach was then added to these three approaches [7]. This brings together the previous arguments and adds value creation shared between society and the firms. Given that these approaches are not mutually exclusive but can in fact turn out to be complementary [6] a number of them can coexist in the same theory [5].

According to Boesso et al. [8] firms will adopt the approach, or a combination of approaches, according to their targets for their different CSR initiatives. Leaving aside the regulation approach, 
founded exclusively on ethical or moral reasons, the descriptive, instrumental, and strategic approaches argue that there is a possible positive relation between CSR and financial results.

A firm which adopts a descriptive approach does so moved by seeking sustainability and approval—"a license to operate" - whether it be a government, a community, or the rest of the stakeholders [9]. It is centered on providing information concerning the Triple Bottom Line indicators (social, environmental, and financial), describing the firm's behavior in its relation with the stakeholders [10]. Sustainability is based on respecting and serving the community and the environment. This is put into practice avoiding behavior that causes social or environmental detriment [11].

Institutional Theory and New Institutionalism are theories that support this approach, being a school of thought focused on the way in which institutions interact and their effects on society. According to this theory, firms seeking to achieve social legitimacy carry out actions, practices, or processes, which are considered appropriate or desirable within the system of regulations, values, and beliefs of the institutional environment.

As to the possible link between the descriptive approach and financial performance aims, it seems hardly likely that firms mean to associate them in the short-term: firms mean to build relations of trust with their interest groups and this takes time [12]. Therefore, by its very nature, the descriptive approach, whose basis is an efficient investment strategy for the future, could contribute to improving the financial performance in the medium term [8].

On the other hand, the instrumental CSR approach is established on its reputation as a means of creating a competitive advantage and of achieving financial performance aims. From this point of view, firms endeavor to commit themselves to those groups of stakeholders which may influence financial performance, creating relations of trust that enable them to attain shared objectives in the most efficient manner possible [13].

One of this approach's underlying theories is Agency Theory [14,15]. This upholds that there is a trustee relation between managers and owners, presenting the shareholders as principals and the managers as agents of the owners or shareholders. One of the management's interests is to achieve a good reputation with the shareholders, reducing the conflicts stemming from the principal-agent relation by applying socially responsible practices.

However, decision-making becomes more complex if the preferences of other groups, as well as the interests of the shareholders, are taken into account. In this sense, Stakeholder-agency theory [16] proposes that the managers can be considered as agents of all the stakeholders. The latter are differentiated by the importance of their participation in the firm and their power vis-à-vis the executives [17]. There is therefore considerable friction in the stakeholder-executive relationship due to "some participants' ability to retard equilibrating adjustments that are unfavorable to themselves" [6] (p. 78). The stakeholders thus connect with the executives to achieve mutual aims in the most efficient manner possible.

According to Falck and Heblich [18], the instrumental approach can provide the firm with advantages to identify trends or market changes, enabling it to act swiftly in order to stabilize itself and be in the vanguard of change. It can also help firms to proactively construct competences via the analysis of their skills, processes, and systems. This increases the organization's capacity in the face of change, turbulence, and crises [19].

Consequently, according to Greenley et al. [17], the managers who adopt an instrumental CSR approach mean to achieve short-term performance aims. These objectives vary over time. This is due to the preferences of one or another group of stakeholders, according to their capacity to contribute to the firm's aims. In this vein, Boesso et al. [8] find empirical evidence of a relation between the instrumental CSR approach and improved financial performance in terms of short-term measures.

Lastly, under the strategic approach, CSR goes beyond behaving as a "good citizen" or mitigating the possible negative effects of the organizations on society. It does so by incorporating specific initiatives that generate benefits for the firm and its environment or the context in which it competes. 
As a consequence, the effects of society on the firm and the firm on society come together to construct a shared value: "When value chain practices and investments in competitive context are fully integrated, CSR becomes hard to distinguish from the day-to-day business of the company" [7] (p. 89).

In this line, Freeman [20] proposed the so-called Stakeholder Theory, in which he argues that paying systematic attention to the interests of the different groups is vital for the firm's success. This is because incorporating their demands into the firm's decisions can generate valuable intangible assets, as they may be a source of competitive advantages. At the beginning, therefore, considering the interests of the groups involved plays an instrumental role in the improvement of the firm's results [21].

This theory later evolved to incorporate shared value generation and to integrate ethics and sustainability into the economic perspective of capitalism [22].

CSR hence means a new philosophy that permeates all the organization. It is a new strategic tool for the firm that, along with obtaining profits, takes into account people and the environment. That is to say, it incorporates the triple line of results (social, environmental, and financial) in its strategies, policies, and business operations [23].

In this sense, the potential benefits of CSR have been associated in the literature with developing an appropriate relation with the different stakeholders [12,24-27].

The results of previous research indicate that CSR initiatives can revive or strengthen the differentiation of products in the market [28], refine aspects of efficiency in process costs [29,30], attract better human capital [31,32], and improve other intangible assets, such as business reputation [33].

Together with the Stakeholder Theory, the Theory of Resources and Capacities presents a strategic approach based on firms' internal properties and attributes as a tool for differentiation and competitiveness in the market [34]. Corporate reputation is thus identified as one of the keys to competitive success and is defined as the firm's image, built over time by the different interest groups [35-37]. As it is a source of competitive advantages sustained in the long-term, CSR is among the resources available to firms to achieve a better corporate reputation [38].

The empirical works of Fombrum and Shanley [39], McGuire et al. [40], Hart [41], Hillman and Keim [25], McWilliams and Siegel [42], Porter, and Kramer [7] and Verschoor [43] stand out for having verified the benefits associated with a good reputation.

The relation between the strategic CSR approach and a better financial performance has been considered. Michelon et al. [44] and Tang et al. [45] noted that the positive effect of these initiatives on the business performance is stronger, both in market and accounting performance measures, when a firm seeks CSR initiatives that are related with the preferences of its stakeholders. On the other hand, Boesso et al. [8] argue the possibility of attaining of financial aims in both the short and the medium term, as they define the strategic approach as a combination of the descriptive approach and the instrumental approach. Nonetheless, authors such as Porter and Kramer [46] and Wang and Bansal [47], among others, relate the strategic CSR approach with the long-term financial performance aims. This is because when CSR is conceived as specific actions isolated from the business strategy, inconveniences such as the monetary cost or agency problems between the owners and the managers may absorb its benefits or advantages.

This work's empirical study analyzes the possible existence of differences in the short and long-term financial performance for Spanish listed responsible firms. There is empirical evidence concerning the differences in the relation studied when it is analyzed in the short and long-term [3]. In the works of Ogden and Watson [48] and García-Castro et al. [49], while CSR has a negative impact on profitability in the short-term, the sign of the relation becomes positive in the long-term. Also, López et al. [50] find that the negative link of the first years between social and financial performance loses its intensity in the medium and long-term. Nevertheless, there are also works that show a positive impact of CSR on the performance variables in the short-term, such as a growth of sales and no relation of a long-term impact in variables, such as the accounting cost [51]. 


\section{Empirical Study}

This empirical research work includes two differentiated studies:

1. A cross-sectional study carried out at the time of the publication of the Spanish responsible index, where we analyze the possible existence of differences in the financial behavior of the firms belonging to the FTSE4Good IBEX in 2008 and compare these firms to others which were not included in the index because of not meeting the requirements.

2. A longitudinal study from 2008 to 2013 , where we analyze if the firms which made up the FTSE4Good IBEX in 2008 and which were still in it in 2013, differ in their financial performance from those firms which have never been part of the sustainable index during this period.

\subsection{Cross-Sectional Study}

In the cross-sectional study carried out when the Spanish responsibility index was published, the hypothesis proposed was that the firms included in the FTSE4Good IBEX in 2008 might differ in their financial-economic variables with respect to firms included in IBEX, its reference stock index.

The FTSE4Good's selection system, based on globally recognized codes of conduct, includes both negative or exclusion criteria and positive or inclusion criteria. This assures the fulfillment of social and environmental standards, as well as the dialogue of investors with the firm and the exercising of voting rights to encourage firms to improve their social or environmental performance.

As to the exclusion criteria, the FTSE rejects firms that produce tobacco and those that make nuclear arms. The inclusion criteria have to do with the management of environmental risks, climate change, human and labor rights, work standards in the supply chain, and the rejection of corruption, among others.

To verify the hypothesis proposed, our study population was the 87 firms that comprise the FTSE4Good IBEX source indexes. We considered as responsible firms the 32 that belonged to the FTSE4Good IBEX in November 2008. The remaining 55 firms were not qualified as such.

Discriminant analysis was used, being appropriate to identify which variables enable the distinguishing between the two groups of firms. As discriminant analysis is categorical, a logistic regression was additionally carried out to include the sector variable.

Social performance was defined as a dummy variable that takes value 1 if the firm belongs to the responsible index and 0 if it does not. Both accounting variables and market variables were used as financial performance indicators. The financial-economic information of the firms that make up the sample was taken from the SABI database (Iberian Balance Sheets Analysis System). The variables that require stock information refer to the November 2007 to November 2008 period. The rest of the variables that need accounting information correspond to the financial year 2007.

This alternative of combining both types of measures is the one most recommended in previous research works. Furthermore, it was considered fitting to include the control variables most studied, due to their possible influence: size, debt ratio and sector (Table 1).

The results of the logistic regression showed that the sector the firm belongs to do not make a difference between the two groups of firms. As to the rest of the variables, the logistic regression indicated the Beta coefficient and the debt ratio as those having a significance coefficient of $95 \%$ (Table 2).

Concerning the discriminant analysis, an initial function D1 was calculated from the standardized coefficients of the canonic discriminant functions. Its capacity to differentiate between groups is evaluated through Wilks' lambda, checking if the differences of the measures of the two groups are significant.

$$
\mathrm{D} 1=0.198 \mathrm{VOL}+0.461 \alpha+0.232 \beta+0.191 \mathrm{PBV}+0.425 \mathrm{DBT}-0.130 \mathrm{ROE}+0.484 \mathrm{SZE}-0.265 \mathrm{EPS} .
$$

where VOL $=$ Volatility, $\alpha=$ Alfa, $\beta=$ Beta, $\mathrm{PBV}=$ Price to book value, $\mathrm{DBT}=$ Debt ratio, $\mathrm{ROE}=$ Return on equity, $\mathrm{SZE}=$ Size, $\mathrm{EPS}=$ Earnings per share. 
The Wilks' lambda of this initial discriminant function (0.796) is statistically significant. Yet, being close to 1 , it is not powerful enough to make differences between the groups.

Table 1. Financial performance variables.

\begin{tabular}{ll}
\hline \multicolumn{1}{c}{ Variable } & \multicolumn{1}{c}{ Description } \\
\hline Alpha coefficient & Excess yield on systematic risk of security \\
\hline Beta coefficient & Systematic risk of security \\
\hline Volatility & Degree of fluctuation in the share price \\
\hline Return on equity (ROE) & Ratio between net income and shareholder's equity \\
\hline Earnings per share & Ratio between net income and number of shares \\
\hline Price to book value & Share Price divided by the book value per share \\
\hline Debt ratio & Total liabilities divided by total assets \\
\hline Size & Natural logarithm of the total assets \\
\hline Sector & $\begin{array}{l}\text { Dummy variable, which takes value } 1 \text { if the company belongs to the service sector } \\
\text { and value } 0 \text { if it is an industrial company }\end{array}$ \\
\hline
\end{tabular}

Table 2. Logistic regression results.

\begin{tabular}{ccccccccc}
\hline & B & S.E. & Wald & df & Sig. & Exp(B) & \multicolumn{2}{c}{ 95\% C.I. for EXP(B) } \\
\cline { 6 - 9 } & & & & & & & Lower & Upper \\
\hline Sector & -0.210 & 0.558 & 0.142 & 1 & 0.706 & 0.810 & 0.272 & 2.418 \\
Alpha coefficient & 3.393 & 1.749 & 3.762 & 1 & 0.052 & 29.754 & 0.965 & 917.259 \\
Beta coefficient & 2.269 & 1.001 & 5.136 & 1 & 0.023 & 9.671 & 1.359 & 68.822 \\
Price to book value & 0.001 & 0.028 & 0.001 & 1 & 0.970 & 1.001 & 0.947 & 1.058 \\
Debt ratio & 2.537 & 1.036 & 5.994 & 1 & 0.014 & 12.647 & 1.659 & 96.425 \\
ROE & -0.003 & 0.008 & 0.141 & 1 & 0.707 & 0.997 & 0.983 & 1.012 \\
Earnings per share & -0.148 & 0.202 & 0.542 & 1 & 0.462 & 0.862 & 0.581 & 1.280 \\
\hline
\end{tabular}

Therefore, in a second phase, the variables were selected which contribute to minimizing this value. Table 3 shows how the variables that succeed in discriminating between the firms belonging to one group or another are the Alpha coefficient, the Beta coefficient, the debt ratio, and the size. These are the variables considered to elaborate the final discriminant function (D2). Its Wilks' lambda $(0.821)$ tha is statistically significant. This indicates that the function has the capacity to distinguish between groups.

$$
\mathrm{D} 2=0.365 \alpha+0.431 \beta+0.528 \mathrm{DBT}+0.324 \mathrm{SZE}
$$

where $\alpha=$ Alfa, $\beta=$ Beta, DBT $=$ Debt ratio, SZE $=$ Size.

Table 3. Test of equality of group means.

\begin{tabular}{cccccc}
\hline & Wilks' Lambda & F & df1 & df2 & Sig. \\
\hline Volatility & 1.000 & 0.001 & 1 & 84 & 0.978 \\
Alpha coefficient & 0.944 & 4.965 & 1 & 84 & 0.029 \\
Beta coefficient & 0.951 & 4.302 & 1 & 84 & 0.041 \\
Price to book value & 0.996 & 0.318 & 1 & 84 & 0.574 \\
Debt ratio & 0.922 & 7.112 & 1 & 84 & 0.009 \\
ROE & 1.000 & 0.001 & 1 & 84 & 0.975 \\
Size & 0.867 & 12.939 & 1 & 84 & 0.001 \\
Earnings per share & 0.997 & 0.282 & 1 & 84 & 0.596 \\
\hline
\end{tabular}




\subsection{Longitudinal Study}

The following hypothesis is proposed in the longitudinal study: firms belonging to the FTSE4Good IBEX social responsibility index will in the long-term achieve a greater financial performance than those firms which do not belong to this index.

To verify this hypothesis, we analyzed if the performance indicators of firms that were in the sustainable index when it appeared and remained in it during the 2008/2013 period (23 firms) were different from those which have never been in this index (37 firms).

Based on the literature review carried out concerning the financial performance measure used in the empirical research, and following the trend of employing Return on equity (ROE) along with Return on assets (ROA), the study of this financial performance measure is considered appropriate $[52,53]$. Tobin's $Q$ is included due to the relevance of this variable in the literature on CSR, especially in recent years [30,54-58].

The variables that record the different aspects of financial performance, and also the control variables (size, debt ratio, and sector) are shown in Table 4. Social performance (FTSE) is defined as belonging to the responsible index in the 2008/2013 period (Box 1).

Table 4. Financial performance variables.

\begin{tabular}{ll}
\hline \multicolumn{1}{c}{ Variable } & \multicolumn{1}{c}{ Description } \\
\hline Alpha coefficient & Excess yield on systematic risk of security \\
\hline Beta coefficient & Systematic risk of security \\
\hline Return on equity (ROE) & Ratio between net income and shareholder's equity \\
\hline Return on assets (ROA) & Ratio between net income and total assets \\
\hline Earnings per share & Ratio between net income and number of shares \\
\hline Tobin's Q & Ratio between market value + liabilities and total assets \\
\hline Debt ratio & Total liabilities divided by total assets \\
\hline Size & $\begin{array}{l}\text { Natural logarithm of the total assets (Transforming the asset in the Napierian } \\
\text { logarithm of its value avoids the problems derived from the lack of normality in } \\
\text { this variable's distribution) }\end{array}$ \\
\hline Sector & $\begin{array}{l}\text { Dummy variable, which takes value 1 if the company belongs to the service } \\
\text { sector and value } 0 \text { if it is an industrial company }\end{array}$ \\
\hline
\end{tabular}

Box 1. Social performance variable.

Corporate social responsibility: Belonging to the responsible index. Dummy variable with two levels: 0 for the firms which comprise the eligible universe index but have not been in it during the period analyzed, and 1 for the firms which belonged to the FTSE4Good IBEX in 2008 and remained in it until 2013.

Time: 6 levels, years 2008/2013

For the FTSE variable ( 0 and 1$)$, the analysis of frequencies shows that 36 firms do not belong to the responsible index (value 0 ) and 22 firms do belong to it (value 1): $62.1 \%$ as compared to $37.9 \%$.

The sector variable also has two categories (0 and 1), 22 firms belong to the industrial sector (value 0 ) and 36 firms are in the services sector (value 1): $37.9 \%$ as compared to $62.1 \%$.

A two-factor Mixed ANOVA was carried out to evaluate the individual and joint effect of belonging to the responsible index (inter-subject factor) and of time (intra-subject factor) on the different financial performance variables.

Of the effects analyzed, it is the interaction between time and belonging to the index that indicates the possible existence of differences over time between the two groups of firms considered.

Regarding the study of the control variables via the Chi-squared test, the possible existence of a significant relation between belonging to the social responsibility index and the sector is analyzed. 
Table 5 shows that as its significance level is over 0.05 , the sector is not a variable that affects the relation between belonging to the index and financial performance.

Table 5. Chi-Square Tests.

\begin{tabular}{cccccc}
\hline & Value & df & Asymp. Sig. (2-Sided) & Exact Sig. (2-Sided) & Exact Sig. (1-Sided) \\
\hline Pearson Chi-Square & 0.134 & 1 & 0.715 & & \\
Continuity Correction & 0.007 & 1 & 0.931 & & \\
Likelihood Ratio & 0.133 & 1 & 0.715 & 0.784 \\
Fisher's Exact Test & & & 0.717 & \\
Linear-by-Linear Association & 0.131 & 1 & & \\
N of valid cases & 58 & & &
\end{tabular}

Regarding the possible relation between the other two control variables-the size and the debt ratio-and belonging to the responsible index, the ANOVA results show that the size is significantly different over time in the two groups analyzed, while the debt ratio is similar in both groups of firms (Table 6).

Table 6. ANOVA FTSE-Size and FTSE-Debt ratio.

\begin{tabular}{ccccc}
\hline & $\mathbf{F}$ & $\mathbf{d f}$ & $\boldsymbol{p}$ & $\boldsymbol{\eta}_{\mathbf{p}}{ }^{2}$ \\
\hline Size*Time $^{*}$ & 13.880 & 1.739 & 0.000 & 0.199 \\
Size*FTSE*Time $_{\text {Size FTSE }}$ & 6.407 & 1.739 & 0.004 & 0.103 \\
Debt ratio*Time & 33.453 & 1.56 & 0.000 & 0.374 \\
Debt ratio*FTSE*Time & 0.795 & 2.575 & 0.482 & 0.014 \\
Debt ratio*FTSE & 1.415 & 2.575 & 0.134 & 0.034 \\
\hline
\end{tabular}

The analysis begins by carrying out Box's test for equality of variances-covariances matrices. In the Mixed Factorial ANOVA, as well as the sphericity test, an additional supposition must be established: that the matrices of the intra-subject factor must be equal in each of the inter-subject levels. If the value obtained in Box's test is significant, the null hypothesis is rejected and it is concluded that the matrices are not statistically equal. In this case, it is necessary to adjust the degrees of freedom of the theoretical F using the correction coefficients (epsilon), as is hereafter explained. In the case of accepting the null hypothesis, it is concluded that the matrices are equal and the sphericity test will, in the case of not being proven, indicate the need to apply the correction coefficients. This only takes place in the case of the Beta coefficient.

The sphericity of the matrix of the design's covariances is then validated via Mauchly's sphericity test. If the sphericity test provides a significant value, the sphericity cannot be assumed and it is therefore necessary to evaluate the epsilon values to select the most appropriate correction. To be able to use the F statistic in non-sphericity conditions, the degrees of freedom of F must be corrected, multiplying them by the estimated value of epsilon. In the study carried out, this takes place for all of the variables and given that the significance level of epsilon is $<0.75$, than the Greenhouse-Geisser correction must be used.

Table 7 shows the results obtained by the Mixed ANOVA—one for each variable of the financial performance. 
Table 7. ANOVA results.

\begin{tabular}{|c|c|c|c|c|}
\hline & F & df & $p$ & $\eta_{\mathrm{p}}^{2}$ \\
\hline Alpha coefficient*Time & 0.661 & 1.001 & 0.420 & 0.012 \\
\hline Alpha coefficient ${ }^{*}$ FTSE $^{*}$ Time & 0.636 & 1.001 & 0.429 & 0.011 \\
\hline Alpha coefficient*FTSE & 0.737 & 1.56 & 0.394 & 0.013 \\
\hline Beta coefficient ${ }^{*}$ Time & 8.104 & 3.735 & 0.000 & 0.126 \\
\hline Beta coefficient*FTSE*Time & 3.124 & 3.735 & 0.018 & 0.053 \\
\hline Beta coefficient*FTSE & 14.643 & 1.56 & 0.000 & 0.207 \\
\hline ROA*Time & 7.477 & 2.361 & 0.000 & 0.120 \\
\hline ROA*FTSE*Time & 0.814 & 2.361 & 0.463 & 0.015 \\
\hline ROA*FTSE & 0.001 & 1.55 & 0.978 & 0.000 \\
\hline ROE*Time & 5.909 & 2.410 & 0.002 & 0.097 \\
\hline ROE $^{*}$ FTSE $^{*}$ Time & 1.544 & 2.410 & 0.213 & 0.027 \\
\hline ROE*FTSE & 2.620 & 1.55 & 0.111 & 0.045 \\
\hline Tobin's Q*ime & 1.065 & 2.343 & 0.356 & 0.019 \\
\hline Tobin's Q*TSE*Time & 1.691 & 2.343 & 0.183 & 0.030 \\
\hline Tobin's Q*FTSE & 1.381 & 1.55 & 0.245 & 0.024 \\
\hline Earnings per share ${ }^{*}$ Time & 0.164 & 1.723 & 0.817 & 0.003 \\
\hline Earnings per share*FTSE*Time & 0.141 & 1.723 & 0.839 & 0.003 \\
\hline Earnings per share ${ }^{*}$ FTSE & 0.292 & 1.55 & 0.591 & 0.005 \\
\hline
\end{tabular}

Of all the variables analyzed, the Beta coefficient presents differences over time in both groups of firms.

\section{Discussion of Results}

The results of the cross-sectional study carried out in 2008, when the Spanish responsibility index was created, show that the FTSE4Good IBEX firms have a greater systematic or market risk, an added profitability for the same level of systematic risk, a higher debt ratio, and a larger size.

On the other hand, the longitudinal study indicates that the firms which belonged to the FTSE4Good IBEX during the 2008/2013 period have a greater systematic risk and a larger size than conventional firms.

Regarding the market risk (Beta coefficient), both analyses show a greater sensitivity of the firms in the sustainability index to the movements of market prices, though its average value is less than 1 . Their shares can thus be qualified as defensive in the face of stock fluctuations. This result is in line with that of Miralles et al. [59] in the Spanish stock market for the 2001-2010 period.

However, the literature also argues the possible existence of a negative relation between the dissemination of responsible practices and systematic risk. Firms with this kind of behavior could gain the trust of investors and be seen as less risky investments. This is due to this behavior's capacity to improve access to capital and even the productivity of the firm's employees, contributing to making its market values more stable [60].

In this respect, the literature also suggests the greater impact that measures linked to reputation have on systematic risk as compared to the rest of the CSR indicators. A firm's social performance must be visible for it to have an impact on its risk. Without visibility it cannot be identified as a clear indication of the firm's success in trying to satisfy the interests of the different stakeholders [39]. In this vein, Herremans et al. [61] concluded that a good reputation for social responsibility is significantly related with the firm's low total risk.

It has also been claimed that the market's reactions to investments in social performance are more immediate and stronger than the fluctuations in the internal accounting profitability measures. This is due to potential investors and lenders interpreting a low level of social responsibility as a lack of the managerial skills required to gradual gain a reputation $[62,63]$. They therefore perceive the firm's future, and hence its shares, as riskier. Furthermore, if both of the potential investors and lenders use the filters of socially responsible investment, a low level of social performance will restrict the access to capital. This will undoubtedly contribute to increasing the firm's financial risk [63]. 
As regards size, Orlitzky [64] concludes that large firms adopt more responsible behavior than small firms, and that the positive correlation between financial and social performance is maintained when the size is controlled. Moore [65] also found a greater social responsibility in older and larger firms and argued that larger firms are more prone to suffer damage to their reputation if they do not carry out social responsibility measures. More recently, Nelling and Webb [66], and Arora and Dharwadkar [67] obtained the same results.

In this vein, the work of Agudo et al. [68], which proposes a model to evaluate the social performance of a sample of 416 Spanish firms from the perceptions of their managers, finds a positive relation between the firm's size and its level of social performance. Consequently, firms that achieve better social results are for the main part medium and large firms. However, the firms that have a low social performance are mostly small and micro-firms. This work also connects social performance with other aspects. The sector distribution is a criterion that does not make a difference between firms with high, medium, and low CSR scores. The degree of familiarization with CSR shows that more responsible firms have more knowledge about it. Lastly, the majority of firms perceive very little pressure from their interest groups. Yet most of the firms that notice this pressure have a high social performance.

Nevertheless, there are works, such as that of Udayasankar [69], which uphold that small firms can also be motivated to adopt initiatives in the CSR field. Their low visibility means that the marginal utility that they obtain from improving their image is greater and that they can also propose CSR as a means of achieving financial resources, given that they have a more restricted access to them.

Although the literature has determined the decisive role of the activity sector [70] in adopting responsible practices, the sector is not a differentiating variable between the two groups of firms in our analyses. The differences derived from the intensity of the work force, the capital requirements, and the potential of generating residues can also be connected with the development of CSR practices $[61,71,72]$. While industrial firms are required by law and by the stakeholders to consider social and environmental practices in their production process, services firms receive less pressure in this respect. Notwithstanding, there are works which have observed that social performance is greater in services firms, such as financial bodies, than in heavy manufacturing industries [65]. On the other hand, Waddock and Graves [73] and Brammer et al. [74] confirm the influence of the sector in the relation between social performance and financial performance.

The greater profitability concerning market risk (Alpha coefficient) obtained by the sustainable index firms for 2008 is not maintained over the 2008/2013 period. In this line, Miralles et al. [59] confirm that responsible firms do not obtain added market profitability. This is negative, though not significantly different from that of conventional firms.

They are also valued by the market in a similar way to conventional firms (Tobin's Q) for the $2008 / 2013$ period. In this sense, the literature indicates that investors do not associate better social and environmental results with a greater profitability in the Spanish case. If they did, they would demand less profitability from responsible firms, given that they would consider them to be less risky. Between these two extremes is the scenario in which the market does not efficiently put a price on CSR. That is, the assets of responsible firms can be initially undervalued or overvalued and produce a greater or lesser profitability as adjusted by risk, respectively. But the action of the arbitragers, who detect these differences, eliminates the inefficiency of the market, shifting the efficiency frontier [51].

As to the remaining accounting measures of financial performance (ROE, ROA, and Earnings per share), both the longitudinal analysis and the cross-sectional analysis show similar values for both groups of firms. In this line, the results of the works of Setó and Angla [75] in their study of the firms of the MERCO do not present significant differences in the ROE of these firms.

Regarding the debt ratio as an indicator of financial risk, the social responsibility index firms had a greater financial risk in the year the index appeared. But this is not a differentiating characteristic between the two groups of firms over the 2008/2013 period. This result is in line with those of Moore [65], Prior et al. [76], and Nelling and Webb [66], in which the relation between social 
performance and the debt ratio is not significant. Nonetheless, in this respect, the literature indicates that a positive relation between CSR practices and the debt ratio should be expected, given that to access external financing responsible firms ought to fulfill the expectations of the creditors about social and environmental requirements [77]. On the other hand, firms with a high level of debt ratio could be more inclined to adopt CSR measures with the intention of reducing the firm's total risk, and avoiding sanctions and environmental damage [67].

However, has also been indicated that the less a firm's financial risk, the more accurate and credible its financial planning will be and the more capital it will be able allocate to carry out social activities. The sign of this relation is therefore negative [64,78]. In this line, the work of Lima et al. [52] finds a negative impact of the debt ratio on the CSR activities of Brazilian firms.

\section{Conclusions}

Some of the results obtained in the cross-sectional study are consolidated in the long-term study. Firstly, the profitability of the responsible firms' shares is more sensitive to the market's variation of profitability. In this sense, it must be pointed out that they are also maintained as defensive shares over the 2008/2013 period, the average value of the Beta coefficient being less than 1 . This makes it clear that they are not appropriate values for speculative and aggressive management. What is more, this result enables us to state that in the case of the Spanish sustainable index firms, belonging long enough in the index for this information to permeate the market has not caused them to be seen as less risky firms and for that to be translated into an improvement of their market risk. This result suggests that CSR is not sufficiently valued in the Spanish stock market.

Secondly, the greater that size of the firms that maintain responsible behavior in the long-term is also noted. This shows the relevance that larger firms give to preserving their reputation. Being more visible makes them become firms that are more liable to see their image harmed by not fulfilling requirements in the social and environmental questions that their environment demands.

Thirdly, the composition of the Spanish responsibility index does not include sectors that, due to the legal demands applicable to their activity or the social pressure that they receive, would be expected to stand out in the fulfilling of CSR practices.

Lastly, not even in the long-term do the accounting indicators of profitability show significant differences between responsible firms and conventional firms. In this sense, it can be said that in accordance with Stakeholders Theory, to consider the interests of the rest of the interest groups along with the interests of the shareholders does not mean that the latter obtain less profitability and that their interests are harmed as a result.

Other results, obtained in the first study, are not maintained in the longitudinal study. The greater stock profitability for the responsible firm's systematic risk level in the first year of the index is not sustained in the long-term. This result confirms the existing empirical evidence for the Spanish listed market that the firms with better CSR practices do not gain additional market profitability. However, nor in the long-term do the rest of the profitability indicators regarding the market present differences. This result indicates that the Spanish stock market does not penalize socially responsible investors. Their profitability is similar to that of conventional firms. Nonetheless, for the responsible index firms to sustain a greater stock profitability it would certainly mean an incentive for a greater development of CSR in Spain.

Concerning the FTSE4Good IBEX firms' higher level of their debt ratio in the year that it appeared, this positive relation could be explained by the need to reduce the creditors' perception of the firms' financial risk. Yet responsible firms and conventional firms present similar levels of financial risk in the long-term. This implies that being socially responsible is not connected with a greater financial risk, though the literature links this type of behavior to possible higher costs.

Therefore, these results leave a path open for a greater development of CSR. It has been determined in the analyses carried out that to be responsible does not mean less stock profitability or a lower business result. It certainly contributes to firms continuing to voluntarily incorporate 
good CSR practices into their business models. They will thus respond to the pressures of a society that is increasingly more aware of social and environmental problems and which, via information technologies, has a greater capacity to control and denounce irresponsible behavior in these areas.

Moreover, and in spite of the weak level of development of socially responsible investment in Spain as compared to other European Union countries, having a sustainable stock index for the Spanish market helps to satisfy significant groups of investors who are guided by their criteria to select a destination for their funds. These criteria enable listed firms to elaborate their CSR policies based on internationally recognized principles and facilitate their access to the responsible investment market. Belonging to a sustainable stock index allows firms to communicate their CSR results and to improve and strengthen their reputation.

The use of a sole social performance indicator is one of this work's limitations. Nevertheless, this presents the advantage of including different social and environmental criteria. Hence, it becomes a multidimensional indicator and, as it is a public and internationally recognized index, it has a greater homogeneity and objectivity than other existing local indexes. The responsible indices-specifically, one of those which is considered most relevant, the FTSE4Good Index, which is used in this work-can be of great use for governments when establishing public policies. Among the users most interested in these indices are the very firms which belong, have belonged, or wish to belong to an index, as they can use them as instruments to improve their practices and, in some cases, as instruments of managing their reputation.

Also, the date the index was created limits in the study's time horizon to the 2008/2013 period. In this sense, as there are studies which identify the moderator effect of the environment's conditions, it can be considered that the results have been affected by the economic circumstances. To verify this possible impact, it could be analyzed if the results are maintained at the end of 2012, which is when the Stock Market trend changed. Lastly, the period analyzed may not be long enough for other differences between the groups of firms to begin to emerge.

Acknowledgments: The authors thank the anonymous reviewers for their insightful comments and suggestions.

Author Contributions: This article is a joint work of the three authors. Ismael Moya was involved in the conception and design of the paper, and the theoretical foundations. Maria J. Charlo participated in the analysis of the results and contributed to write the paper. Ana M. Muñoz contributed to data collection and analysis and to write the paper. All authors participated in the literature review and gave thought to the conclusions. All authors read and approved the submitted manuscript.

Conflicts of Interest: The authors declare no conflict of interest.

\section{References}

1. Lu, W.; Chau, K.W.; Wang, H.; Pan, W. A decade's debate on the nexus between corporate social and corporate financial performance: A critical review of empirical studies 2002-2011. J. Clean. Prod. 2014, 79, 195-206. [CrossRef]

2. Reverte, C. Determinants of corporate social responsibility disclosure rating by Spanish listed firms. J. Bus. Ethics 2009, 88, 351-366. [CrossRef]

3. Van Beurden, P.; Gössling, T. The worth of Values-A literature Review on the Relation between Corporate Social and Financial Performance. J. Bus. Ethics 2008, 82, 407-424. [CrossRef]

4. Inoue, Y.; Lee, S. Effects of different dimensions of corporate social responsibility on corporate financial performance in tourism-related industries. Tour. Manag. 2011, 32, 790-804. [CrossRef]

5. Garriga, E.; Melé, D. Corporate Social Responsibility Theories: Mapping the Territory. J. Bus. Ethics 2004, 53, 51-71. [CrossRef]

6. Donaldson, T.; Preston, L.E. The Stakeholder Theory of the Corporation: Concepts, Evidence and Implications. Acad. Manag. Rev. 1995, 20, 65-91.

7. Porter, M.E.; Kramer, M.R. The Competitive Advantage of Corporate Philanthropy. Harv. Bus. Rev. 2002, 80, 56-68. [PubMed] 
8. Boesso, G.; Kumar, K.; Michelon, G. Descriptive, instrumental and strategic approaches to corporate social responsibility: Do they drive the financial performance of companies differently? Account. Audit. Account. J. 2013, 26, 399-422. [CrossRef]

9. Fombrun, C.J. Realizing Value from the Corporate Image; Harvard Business School Press: Boston, MA, USA, 1996.

10. Berman, S.L.; Wicks, A.C.; Kotha, S.; Jones, T.M. Does stakeholder orientation matter? The relationship between stakeholder management models and firm financial performance. Acad. Manag. J. 1999, 42, 488-506. [CrossRef]

11. Clement, R.W. The lessons from stakeholder theory for US business leaders. Bus. Horiz. 2005, 48, $255-264$. [CrossRef]

12. Choi, J.; Wang, H. Stakeholder relations and the persistence of corporate financial performance. Strateg. Manag. J. 2009, 30, 895-907. [CrossRef]

13. Jones, T.M.; Felps, W.; Bigley, G.A. Ethical theory and stakeholders-related decisions: The role of stakeholder culture. Acad. Manag. Rev. 2007, 32, 137-155. [CrossRef]

14. Jensen, M.C.; Meckling, W. Theory of the Firm: Managerial Behaviour, Agency Cost, and Capital Structure. J. Financ. Econ. 1976, 3, 305-360. [CrossRef]

15. Ross, S. The Economy Theory of the Agency: The Principal's Problem. Am. Econ. Rev. 1973, 63, 134-139.

16. Hill, C.L.; Jones, T.M. Stakeholder-agency theory. J. Manag. Stud. 1992, 29, 131-154. [CrossRef]

17. Greenley, G.E.; Hooley, G.J.; Broderick, A.J.; Rudd, J.M. Strategic planning differences among different multiple stakeholder orientation profiles. J. Strateg. Mark. 2004, 12, 163-182. [CrossRef]

18. Falk, O.; Heblich, S. Corporate Social Responsibility: Doing well by doing good. Bus. Horiz. 2007, 50, $247-254$. [CrossRef]

19. Orlitzky, M.; Schmidt, F.; Rynes, S.L. Corporate Social and Financial Performance: A meta-Analysis. Organ. Stud. 2003, 24, 403-441. [CrossRef]

20. Freeman, R.E. Strategic Management: A Stakeholder Approach; Pitman: Boston, MA, USA, 1984.

21. Laplume, A.O.; Sonpar, K.; Litz, R.A. Stakeholder Theory: Reviewing a Theory that Moves Us. J. Manag. 2008, 34, 1152-1189. [CrossRef]

22. Freeman, R.E.; Harrison, J.S.; Wicks, A.C.; Parmar, B.L.; De Colle, S. (Eds.) Stakeholder Theory. The State of the Art; Cambridge University Press: Cambridge, UK, 2010.

23. Greenberg, D.; McKone-Sweet, K.; Wilson, H.J.; Babson College Faculty. The New Entrepreneurial Leader Developing Leaders Who Shape Social and Economic Opportunity; Berrett-Koehler: San Francisco, CA, USA, 2011.

24. Harrison, J.S.; John, C.H.S. Managing and Partnering with External Stakeholders. Acad. Manag. Exec. 1996, 10, 46-60.

25. Hilmann, A.J.; Keim, G.D. Shareholder value, stakeholder management, and social issues: What's the bottom line? Strateg. Manag. J. 2001, 22, 125-140. [CrossRef]

26. Ortas, E.; Álvarez, I.; Garayar, A. The Environmental, Social, Governance, and Financial Performance Effects on Companies that Adopt the United Nations Global Compact. Sustainability 2015, 7, 1932-1956. [CrossRef]

27. Roberts, R.W.; Dowling, G.R. Corporate Reputation and Sustainable Superior Financial Performance. Strateg. Manag. J. 2002, 23, 1077-1093. [CrossRef]

28. Klassen, R.D.; Whybark, D.C. The impact of environmental technologies on manufacturing performance. Acad. Manag. J. 1999, 42, 599-615. [CrossRef]

29. Christmann, P. Effects of "best practices" of environmental management on cost competitiveness: The role of complementary assets. Acad. Manag. J. 2000, 43, 663-680. [CrossRef]

30. King, A.; Lenox, M. Exploring the locus of profitable pollution reduction. Manag. Sci. 2002, 48, $289-299$. [CrossRef]

31. Backhaus, K.B.; Stone, B.A.; Heiner, K. Exploring the relationship between corporate social performance and employer attractiveness. Bus. Soc. J. 2002, 41, 292-318. [CrossRef]

32. Johnson, R.A.; Greening, D.W. The effects of corporate governance and institutional ownership types on corporate social performance. Acad. Manag. J. 1999, 42, 564-576. [CrossRef]

33. Margolis, J.D.; Elfenbein, H.A.; Walsh, J.P. Does It Pay to Be Good ... and Does It Matter? A Meta-Analysis of the Relationship between Corporate and Financial Performance; Working Paper; Harvard University: Cambridge, MA, USA, 2009.

34. Russo, M.V.; Fouts, P.A. A resource-based perspective on corporate environmental performance and profitability. Acad. Manag. J. 1997, 40, 534-559. [CrossRef] 
35. Peloza, J. Using corporate social responsibility as insurance for financial performance. Calif. Manag. Rev. 2006, 48, 52-72. [CrossRef]

36. Pil, F.; Holweg, M. The advantages of thinking Small. MIT Sloan Manag. Rev. 2003, 44, 33-39.

37. Smith, N.C. Corporate Social Responsiblility: Whether or How? Calif. Manag. Rev. 2003, 45, 52-76. [CrossRef]

38. Porter, M.E.; Kramer, M.R. Creating Shared Value. Harv. Bus. Rev. 2011, 89, 62-77.

39. Fombrun, C.J.; Shanley, M. What's in a name? Reputation building and corporate strategy. Acad. Manag. J. 1990, 33, 233-258. [CrossRef]

40. McGuire, J.B.; Schneeweis, T.; Branch, B. Perceptions of firm quality: A cause or result of firm performance. J. Manag. 1990, 16, 167-180. [CrossRef]

41. Hart, S.L. A Natural-Resource-Based View of the Firm. Acad. Manag. Rev. 1995, 20, 986-1012.

42. McWilliams, A.; Siegel, D. Corporate Social Responsibility: A Theory of the Firm Perspective. Acad. Manag. Rev. 2001, 26, 117-127.

43. Verschoor, C.C. More evidence of better financial performance. Strateg. Financ. 2003, 5, 18-20.

44. Michelon, G.; Boesso, G.; Kumar, K. Examining the Link between Strategic Corporate Social Responsibility and Company Performance: An Analysis of the Best Corporate Citizens. Corp. Soc. Responsib. Environ. Manag. 2013, 20, 81-94. [CrossRef]

45. Tang, Z.; Hul, C.E.; Rothenberg, S. How Corporate Social Responsibility Engagement Strategy Moderates the CSR-Financial Performance Relationship. J. Manag. Stud. 2012, 49, 1274-1303. [CrossRef]

46. Porter, M.E.; Kramer, M.R. Strategy and Society: The link between Competitive Advantage and Corporate Social Responsibility. Harv. Bus. Rev. 2006, 84, 78-92. [PubMed]

47. Wang, T.; Bansal, P. Social responsibility in new ventures: Profiting from a long-term orientation. Strateg. Manag. J. 2012, 33, 1135-1153. [CrossRef]

48. Ogden, S.; Watson, R. Corporate Performance and Stakeholder Management: Balancing Shareholder and Customer Interests in the U.K. Privatized Water Industry. Acad. Manag. J. 1999, 42, 526-538. [CrossRef]

49. García-Castro, R.; Ariño, M.A.; Canela, M.A. Over the long run? Short run impact and long run consequences of Stakeholder Management. Bus. Soc. 2011, 50, 428-455. [CrossRef]

50. López, M.V.; García, A.; Rodríguez, L. Sustainable Development and Corporate Performance: A Study Based on the Dow Jones Sustainability Index. J. Bus. Ethics 2007, 75, 285-300. [CrossRef]

51. Prado, J.M.; García, I.M.; Gallego, I. Effects of Activist shareholding on corporate social responsibility reporting Practices: An empirical study in Spain. J. Econ. Financ. Adm. Sci. 2012, 17, 7-16.

52. Lima, V.; De Souza, F.; Cortés, F. Corporate social responsibility, firm value and financial performance in Brazil. Soc. Responsib. J. 2011, 7, 295-309. [CrossRef]

53. Mahoney, L.; Roberts, R.W. Corporate social performance, financial performance and institutional ownership in Canadian firms. Account. Forum 2007, 31, 233-253. [CrossRef]

54. Bebchuk, L.; Cohen, A.; Ferrell, A. What Matters in Corporate Governance? Rev. Financ. Stud. 2009, 22, 783-827. [CrossRef]

55. Dowell, G.; Hart, S.; Yeung, B. Do Corporate Global Standards Create or Destroy Market Value? Manag. Sci. 2000, 46, 1059-1074. [CrossRef]

56. Konar, S.; Cohen, M. Does the market value environmental performance? Rev. Econ. Stat. 2001, 83, $281-289$. [CrossRef]

57. Lin, T.T.; Huang, S.L. Application of the modified Tobin's q to an uncertain energy-saving project with the real options concept. Energy Policy 2011, 39, 408-420. [CrossRef]

58. Nakao, Y.; Amano, A.; Matsumura, K.; Genba, K.; Nakano, M. Relationship between environmental performance and financial performance: An empirical analysis of japanese corporations. Bus. Strategy Environ. 2007, 16, 106-118. [CrossRef]

59. Miralles, J.L.; Miralles, M.M.; Miralles, J.L. Performance bursátil de las empresas socialmente responsables. Bus. Quart 2012, 15, 221-230. [CrossRef]

60. Heinkel, R.; Kraus, A.; Zechner, J. The Effect of Green Investment on Corporate Behavior. J. Financ. Quant. Anal. 2001, 36, 431-449. [CrossRef]

61. Herremans, I.M.; Akatharporn, P.; McInnes, M. An Investigation of Corporate Social Responsibility Reputation and Economic Performance. Account. Organ. Soc. 1993, 18, 587-604. [CrossRef]

62. Alexander, G.J.; Buchholz, R.A. Corporate Social Responsibility and Stock Market Performance. Acad. Manag. J. 1978, 21, 479-486. [CrossRef] 
63. McGuire, J.B.; Sundgren, A.; Schneeeweis, T. Corporate Social Responsibility and firm financial performance. Acad. Manag. J. 1988, 31, 854-872. [CrossRef]

64. Orlitzky, M.; Benjamin, J.D. Corporate Social Performance and Firm Risk: A Meta-Analytic Review. Bus. Soc. Rev. 2001, 40, 369-396. [CrossRef]

65. Moore, G. Corporate Social and Financial Performance: An Investigation in the U.K. Supermarket Industry. J. Bus. Ethics 2001, 34, 299-315. [CrossRef]

66. Nelling, E.; Webb, E. Corporate social responsibility and financial performance: The "virtuous circle revisited". Rev. Quant. Financ. Account. 2009, 32, 197-209. [CrossRef]

67. Arora, P.; Dharwadkar, R. Corporate Governance and corporate social responsibility (CSR): The moderating role of attainment discrepancy and organization slack. Corp. Gov. Int. Rev. 2011, 19, 136-152. [CrossRef]

68. Agudo, J.M.; Garcés, C.; Salvador, M. Social responsibility practices and evaluation of corporate social performance. J. Clean. Prod. 2012, 35, 25-38. [CrossRef]

69. Udayasankar, K. Corporate social responsibility and firm size. J. Bus. Ethics 2008, 83, 167-175. [CrossRef]

70. Santis, P.; Albuquerque, A.; Lizarelli, F. Do Sustainable Companies have a better Financial Performance? A Study on Brazilian Public Companies. J. Clean. Prod. 2016, 133, 735-745. [CrossRef]

71. Graves, S.B.; Waddock, S.A. Institutional owners and corporate social performance. Acad. Manag. J. 1994, 37, 1034-1046. [CrossRef]

72. Seifert, B.; Morris, S.A.; Bartkus, B.R. Having, Giving and Getting: Slack resources, Corporate Philanthropy and Firm Financial Performance. Bus. Soc. 2004, 43, 135-161. [CrossRef]

73. Waddock, S.; Graves, S.B. The Corporate Social Performance-Financial performance link. Strateg. Manag. J. 1997, 18, 303-319. [CrossRef]

74. Brammer, S.; Brooks, C.; Pavelin, S. Corporate social performance and stock returns: UK Evidence from disaggregate measures. Financ. Manag. 2006, 35, 97-116. [CrossRef]

75. Setó-Pamies, D.; Angla, J. La naturaleza de la relación entre la Responsabilidad Social de la Empresa (RSE) y el resultado financiero. REDEE 2011, 20, 161-176.

76. Prior, D.; Surroca, J.; Tribó, J.A. Are socially responsible managers really ethical? Exploring the relationship between earnings management and corporate social responsibility. Corp. Gov. Int. Rev. 2008, 16, 160-177. [CrossRef]

77. Roberts, R.W. Determinants of corporate social responsibility disclosure: An application of stakeholder theory. Account. Organ. Soc. 1992, 17, 595-612. [CrossRef]

78. Brammer, S.; Millington, A. Does it pay to be different? An Analysis of the Relationship between corporate social and financial performace. Strateg. Manag. J. 2008, 29, 1325-1343. [CrossRef] 